九州大学学術情報リポジトリ

Kyushu University Institutional Repository

\title{
Accidents of Thai Industry between 2001 and 2017
}

Tungj iratthitikan, Pennapa

Graduate School of Engineering Sciences, Kyushu University

https://doi.org/10.5109/1936221

出版情報：Evergreen. 5 (2)，pp.86-92，2018-06. 九州大学グリーンアジア国際リーダー教育センター バージョン：

権利関係 : 


\title{
Accidents in Thai Industry between 2001 and 2017
}

\author{
Pennapa Tungjiratthitikan,* \\ Graduate School of Engineering Sciences, Kyushu University, Japan \\ *Author to whom correspondence should be addressed, \\ E-mail:3ES15030Y@s.kyushu-u.ac.jp
}

(Received April 26, 2018; accepted June 7, 2018).

\begin{abstract}
Industry in a developing country may experience some operational hazards compared to developed countries. Most safety-related industrial misfortunes might be due to the lack of proper training programs resulted from some economic and educational drawbacks. Thus, the number of accidents in the industry is prone to be high due to the limitation of skills; for example, machine operation and chemical handling, etc. This paper presents the historical statistics of industrial related incidents in Thailand and the industrial estate around Thailand. Types of accident and the number of injuries or deaths from 2000 to 2017 are collated. General effects after the occurrence of the accident will be discussed including the related regulatory acts of Thailand and the case study of some industrial accidents.
\end{abstract}

Keywords: Industrial accident; Industrial safety; Safety regulations; Thai industry

\section{Introduction}

In Thailand, the national strategy plan (2017-2036) is recently legalized as a National Economic and Social Development Plan. The issue 12 of that plan includes the world strategy "industry 4.0". This plan is aimed to make Thailand a developed country within 20 years and to increase the annual per capita (GNP) from the current 4,121 USD to 15,000 USD.

Industry 4.0 was first announced being part of the national industrial policy of Germany in 2013. It mentioned that the Germany's industry in 2033 would enter the new era called a "Smart Industry". Utilization of the automated technologies coupled with the intelligent robots and network technology will be the key feature of the fourth industrial revolution for highly efficient production systems. Robots are introduced to control the machines as well as the work processes instead of human operators by connecting to the computer system. Such a smart industry concept was first introduced by developed countries like the United States, the European Union, Japan and Korea. Industries in such countries have been well-developed with the adaptation of high-tech manufacturing facilities and established safety standards. Moreover, social disparities in those countries are considered relatively lower compared to developing countries such as Thailand.

Social disparities or simply the uneven wealth distribution are often measured using the Gini coefficient. It is a measure of statistical data commonly used as an indicator for the inequality of income distribution or distribution of wealth; the value varies between 0 and 1 . According to the United Nations Development
Programme (UNDP), the Gini coefficient of Thailand reads 0.38 for the years $2010-2015^{1}$. This value serves as an evidence of income inequality in Thailand. Uneven wealth distribution can be attributed to many factors such as social structure, gender equality, race, culture, and especially, access to education. People from low-income family who form as the majority of the population often face limited access to educational opportunities. Despite the free compulsory education provided by the government, poverty-stricken people still turn to be low-wage workers as a result of poor family economic conditions. Thus, those economic woes are passed on to their next generation and it is often difficult to come out of this poverty cycle. Meanwhile, high earners usually gain access to excellent educational opportunities which may further lead to economic prosperity passing down to their offspring. Hence, the solution of social disparities in Thailand may be improved educational access for the society for proper income distribution by providing sufficient career opportunities. Thus, Thailand should step up to industry 4.0 in an appropriate way by maintaining the industrial level 2.0 and 3.0. The industry needs to continue employing people even in the future and gradually replaces human workers with an automatic machinery in the manufacturing system. Such actions will help to avoid unemployment among the working people and hence the income gap yet promoting technological access in the Thai society.

As mention above, Thai industry needs to use human labor in the near future at least for the next 20 years, so the Thai industrial organization is needed the improvement of quality and safety in the factory to 
circumvent accidents to their labors.

In the current economic situation, business owners try to keep up with the rapid changes in the new technologies and increase the productivity. The industry sometimes fails to implement proper safety standards which in turn contributes to the accidents or health issues of the workers such as illnesses due to the handling of hazardous materials. This may cause both short-term and long-term injuries including disability or even death. Apart from the severe impact on the lives of the workers and their family, the industry is also negatively affected due to the shortage of workers which eventually increases the production cost. Most importantly, the industry will suffer from the drop in the efficiency of the labor force resulted from the spread of unsafe workplace.

This article focuses on the industrial accidents occurred in Thailand from the beginning of the $21^{\text {st }}$ century (2001-2016). The influence and impacts of such accidents on the welfare of the workers and the development of industry in Thailand are further discussed.

\section{Background of Thai Industry}

The industrialization in Thailand has started since ancient times in the field of simple handicrafts or household merchandises such as weaving, ironwork, woodcarving, and small liquor or sugar manufacturers. In the reign of King Chulalongkorn (the reign of King Rama V of the Chakri Dynasty), large industrial-scale plants such as factories for mint, rice mills, and sawmill, were constructed by foreign workforce. Moreover, after the World War I, many private sectors begun to invest in the various types of the industrial plants such as cigarette factories, paper mills, soap making plants, soap factories etc. However, the growth of Thai economy and industrial expansion was halted due to the global economic downturn in 1927.

Thailand now is recognized as a newly industrialized country (NIC) $)^{7}$ i.e., it is classified as a country with a higher economic growth rate than the neighboring countries in terms of macroeconomic status but lower than those of developed countries. The current industrialization promotes urbanization and the large-scale movement of the rural or agricultural populations to the large cities, especially near to industrial zone.

After becoming the NIC, the problems of health and safety of factory workers increase in Thailand. Many articles have reported the economic development highlighting the lack of safety implementations in the industry despite the wealth of the country has improved. Annual industrial incident reports show that the growing wealth is followed by the rising number of the accident or illness of the workers ${ }^{2}$.

\section{Thai Industrial Estates and Workers}

Industrial estates mean the areas where the industrial plants are systematically allocated together with basic facilities for workers such as residences, telephone and other necessary services including post offices, banks, shopping centers and gas stations. The industrial estates are developed and established by the Industrial Estate Authority of Thailand (IEAT); under the Ministry of Industry, for diversifying industrial development all over the country.

The first industrial estate in Thailand was established in 1973, named Bangchan Industrial Estate, which covered the area of Min Buri and Bangkapi, Bangkok ${ }^{3)}$. Currently (as per data in 2015), IEAT has established 55 industrial estates dispersed in 17 provinces, where 11 industrial estates are full dominated by IEAT and the rest being co-organized with private sectors ${ }^{4,5}$.

\section{Accidents in Thai Industry}

In 1974, Thailand had 39,501 registered factories. However, this number jumped to 95,510 by the end of 1984. It means, Thai industry has grown more than twice over the past 11 years. The average annual growth rate was more than 10 percent. Along with the industrial growth came the increased numbers of factory-related accident. The history of accidents before the $21^{\text {st }}$ century demonstrates that the number of workers who were affected by the accident increased by 10 times from 4,023 in 1974 to 41,056 in 1984. Surprisingly, the growth rate of accidents was higher than the factory growth. This survey suggests that the industrial accidents are likely to occur more and more in the future and correspondingly the increasing number of victims year after year.

The statistical data show that the casualties per 100 factories were increased from 10 employees in 1974 to 43 in 1984. This translates that the growth of worker accidents is strongly related to faster industrialization. This lesson from the past predicts that if Thai government and relevant divisions do not take any serious action from now, the accidents rate is conceivable to be 100 people per 100 factories in the near future. It is noted that every factory might have one of their workers in danger in such scenarios.

Each accident is a loss to the factory. In addition to the cost of injured workers such as medical fees, payroll or compensation, the factory will temporarily lose production time and will be entangled in other expenses even if there are no injuries found.

It is noted that the amount of compensation for the casualties from the accidents in each year is very high as the number of workers in danger increases. Thus, the huge budget of the factory is wasted for this reason. The number of incidents is tracked from the official statistical compensation record while many factory accidents unknown to the authorities are not accounted for. In the unreported cases, the owner of the factory has taken care of the entire medical expenses for their labor clandestinely. If these unofficial disbursements were 
recorded in the whole statistics, these expenses might be tremendously high.

From Table 1 and Fig. 1(a), the number of accidents in 2001 to 2013 were condensed in the Central region (43\%) and Bangkok (19\%) because of the high factory or industrial estate density in these areas. The five provinces which have the most frequent accidental rate were Chon Buri, Samut Prakan, Bangkok, Rayong, and Samut Sakhon.

Table 1. Number of industrial accidents from 2001 to 2013 divided by the region

\begin{tabular}{|c|c|c|c|c|c|c|c|c|}
\hline \multirow[b]{2}{*}{ Year } & \multicolumn{8}{|c|}{ Number of Accidents } \\
\hline & Bangko & Central & Northeast & North & West & East & South & Total \\
\hline 2001 & 1 & 7 & 1 & 2 & 1 & 6 & 1 & 19 \\
\hline 2002 & 6 & 31 & 4 & 5 & 1 & 12 & 12 & 71 \\
\hline 2004 & 20 & 48 & 8 & 2 & 1 & 11 & 15 & 105 \\
\hline 2005 & 18 & 22 & 1 & 0 & 2 & 3 & 14 & 60 \\
\hline 2006 & 10 & 43 & 8 & 2 & 4 & 11 & 7 & 85 \\
\hline 2007 & 13 & 14 & 3 & 2 & 1 & 8 & 1 & 42 \\
\hline 2008 & 7 & 8 & 1 & 1 & 1 & 7 & 0 & 25 \\
\hline 2009 & 6 & 11 & 0 & 1 & 1 & 4 & 1 & 24 \\
\hline 2010 & 5 & 10 & 1 & 0 & 1 & 5 & 1 & 23 \\
\hline 2011 & 6 & 7 & 1 & 2 & 0 & 1 & 0 & 17 \\
\hline 2012 & 14 & 21 & 3 & 0 & 2 & 4 & 1 & 45 \\
\hline 2013 & 9 & 33 & 8 & 3 & 6 & 13 & 7 & 79 \\
\hline Total & 115 & 255 & 39 & 20 & 21 & 85 & 60 & 595 \\
\hline
\end{tabular}

From Table 2 and Fig. 1(b), it is noted that three main accidents are fire $(66 \%)$, toxic release $(10 \%)$ and explosion (10\%). The chief cause of fire was the short circuit inside the factory, and other reasons were from the work related to heating or sparking of an element, such as welding, grinding, cutting, burning, etc. Furthermore, the accidents caused by toxic release and explosion were related to the handling and storing of hazardous chemicals or materials in the processes such as ammonium gas and metallic dust. Besides these reasons, human error due to the operation without care and proper knowledge accounts for $10 \%$.

Table 2. Number of industrial accidents from 2001 to 2016

\begin{tabular}{ccccc|c} 
& \multicolumn{5}{c}{ Number of Accidents } \\
\hline Year & Fire & Explosion & Toxic release & Others & Total \\
\hline 2001 & 12 & 6 & 0 & 1 & 19 \\
2002 & 50 & 5 & 3 & 9 & 69 \\
2004 & 69 & 14 & 11 & 12 & 106 \\
2005 & 42 & 6 & 7 & 5 & 60 \\
2006 & 50 & 17 & 9 & 9 & 85 \\
2007 & 25 & 4 & 4 & 9 & 42 \\
2008 & 6 & 6 & 5 & 6 & 23 \\
2009 & 17 & 1 & 1 & 5 & 24 \\
2010 & 14 & 2 & 5 & 2 & 23 \\
2011 & 11 & 0 & 0 & 6 & 17 \\
2012 & 30 & 3 & 6 & 7 & 46 \\
2013 & 50 & 7 & 6 & 17 & 81 \\
2014 & 79 & 13 & 18 & 15 & 125 \\
2015 & 81 & 7 & 7 & 10 & 105 \\
2016 & 107 & 7 & 17 & 23 & 154 \\
\hline Total & 643 & 98 & 99 & 136 & 979 \\
\hline
\end{tabular}

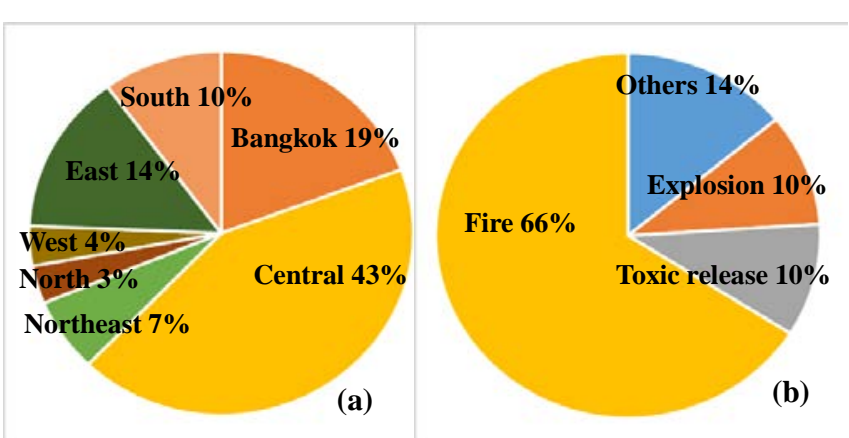

Fig. 1 Information of industrial accidents:

(a) by region (2001-2013)

and (b) by type or nature (2001-2016)

The Department of Industrial Works indicated that a large number of accidents are attributable to the industrial of Textiles and Clothing, Wood processing, Plastic or Rubber, and Chemicals. The accidents reported in the previous three years, i.e., from 2014 to 2016 set a new record since the beginning of the 21 century.

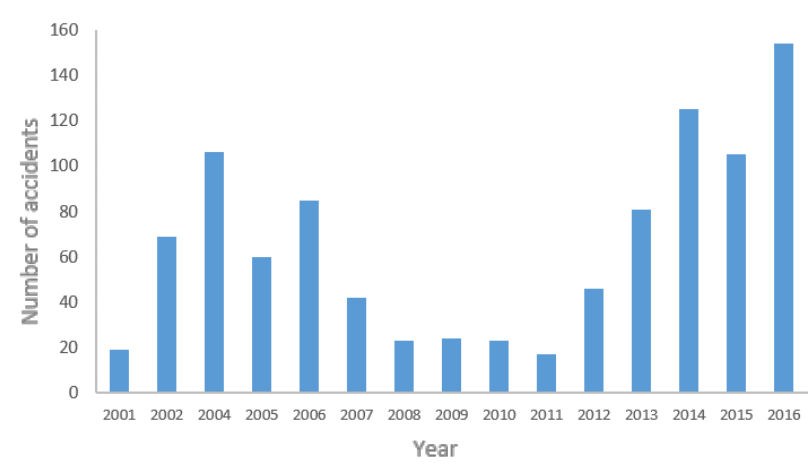

Fig. 2 Number of accidents per year

Fig. 2 indicates that the number of accidents from the year 2001 to 2016. However, it is also noted that the number of industries increases during this period. Thus, it can be postulated that the number of accidents depends on the number of the factory. Therefore, it is important to provide a new or improved safety policy for the prevention of further industrial accidents in order to support the large volume of established factories in the near future.

\subsection{Assessment of injuries and deaths}

The huge number of injuries appeared in 2005 i.e., 339 persons. The top four accidents which show a large number of victims were accidents from toxic release. Three incidents were the leakage of ammonia from the frozen food industries in Ranong, Rayong, and Nakhon Ratchasima provinces. There were 75,64 , and 80 workers injured, respectively, in each accident. A total of 57 injured cases were resulted by the chemical waste vapor from the computer and electronic factory in Ayutthaya. The huge number of deaths (51 persons) were reported in 2004. The biggest accident was an explosion 
of factory for fireworks and matches in Ayutthaya (14 people died) as shown in Table 3 and Fig. 3. Thus, it is clear that the main cause of injury is toxic release while explosion is responsible for the fatalities.

Table 3. Number of injuries and deaths from 2001-2013

\begin{tabular}{c|cc|c|cc}
\hline Year & Injuries & Deaths & Year & Injuries & Deaths \\
\hline 2001 & 29 & 19 & 2008 & 128 & 7 \\
2002 & 119 & 16 & 2009 & 40 & 2 \\
2004 & 222 & 51 & 2010 & 218 & 7 \\
2005 & 339 & 5 & 2011 & 38 & 3 \\
2006 & 131 & 20 & 2012 & 232 & 2 \\
2007 & 118 & 11 & 2013 & 42 & 17 \\
\hline & & & Total & 1656 & 160 \\
\cline { 3 - 5 }
\end{tabular}

However, five ministries of Thailand namely the Ministry of Agriculture and Cooperatives, the Ministry of Transport, the Ministry of the Interior, the Ministry of Public Health and the Ministry of Labor are conducting the safety and health project 2017, or the strategy to stimulate the adoption of safe working policy, especially fire protection in the industry to reduce injury and fatality.

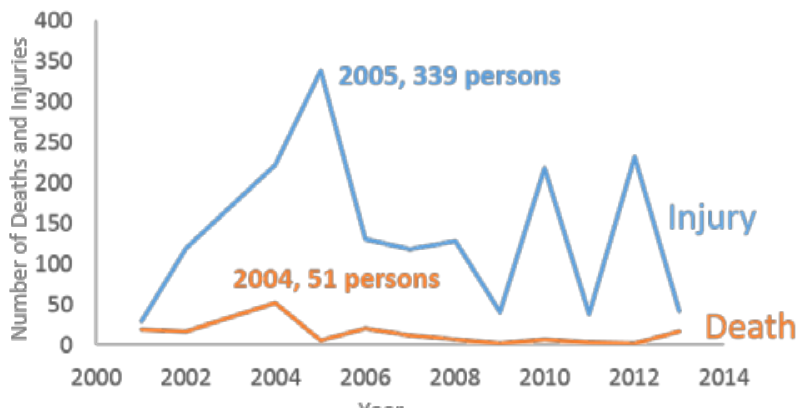

Fig. 3 Number of total injuries and deaths 2001-2013

\subsection{Influence of accidents}

Most accidents, especially, hazardous materials, fire, explosion, and toxic release are due to the irregular handling, storing and managing beyond the approved capabilities. The chemical disasters strongly influence human, plants, animals, and the surrounding environment, including losses of industrial benefits. The accidents occurring at a low level may be served as a precaution for the imminent danger of huge incidents and disasters. Chemical harmfulness may cause long-term destruction. The losses and expenses of the industrial owners due to the accidents can be divided into two categories; as follows:

1. Direct losses; it means the amount of cash to be paid directly (easy to estimate in term of the disbursement) to the injured person which include medical fees, compensation, funeral support money, family support money and life insurance.

2. Indirect losses (Henrich, 1959); it means other expenses excluding the direct costs for each victim. The indirect losses can be further classified into the followings.

2.1 Loss of working time; Victim or injured person losses working time due to their medical treatment, while other workers or colleagues who are temporarily suspended due to the first aid for the injured person, criticism, and panic. The manager of those sections has to investigate the cause and solutions to prevent future accidents and report the incident to the relevant government agencies. The loss of working time might result from recruiting and training other workers to substitute the injured ones.

2.2 Cost of repairing of the damaged machinery and equipment

2.3 Cost related to the discard damaged goods and materials

2.4 Decrease of output due to the disruption of the production process

2.5 Welfare benefits of the injured persons

2.6 Wages of the injured workers paid by the factories despite the inability to work

2.7 Loss of profitability due to the disruption of the production

2.8 Electricity, water, and other rental stuff; the factory still have to pay as usual although the plant must stop or close down its business several days in the case of a serious accident.

2.9 Reputation risk of the factory

In addition to losing workers' life and property, the reputation risk is the huge impact which challenges all the industries to set up their security plan in order to avoid the long-term effects such as hesitancy of the shareholder which results in loss of their market share. Hence, large industries usually pay attention to safety more than small industries to prevent the intervention of a competing company if the reputation is compromised. Thus, the industrial accidents are often associated with the small factories, including household factories because the owners often consider only the short-term benefit such as production cost reduction. To further reduce production cost, some owners utilize machines that may not be suitable and cheap labors without proper knowledge and ability to perform the work.

Accordingly, accidents often occur in small factories. Such accidents often occur in the developing countries because these countries are establishing many of new factory. Small industry may represent as a majority in such economy. Proper inspection by the local authorities might be one of many solutions to the industrial accidents. The local government should check the standards in accordance with the existing relevant regulatory Acts of factories located in their representative regions. Then, the government should issue an industrial license to those factories which passed the safety standards otherwise confiscate those factories or forced them to meet the standards. This government task may raise the awareness of entrepreneurs to operate their 
industries safely.

\subsection{Regulatory Acts of Thailand}

In Thailand, there are many laws and Acts relevant to the safety controls for the establishment and operation of industrial works such as chemicals, machinery, environment, including the welfare of the employees. Several examples of the regulatory acts are as follows:

\section{Factory Act 1992 a}

The main content of this Factory Act is; Specify the factory classification, factory setting criteria, including type, or size of the machinery and how to operate, Define the standards and methods of emissions, pollutants or any other factors of the plant operation which have significant impact to the surrounding environment, Control of the waste generator and waste disposal organization, Obligatory request in the preparation of the required documents and reports, and Provide the rule of license, fees, and legal punishment.

\section{The Hazardous Substance Act 1992 b}

Regulations of hazardous substances for the imported and exported products, sale, transportation and storage of chemicals are divided into 4 safety levels as follows,

Type 1. Hazardous substances must be in accordance with the prescribed rules and procedures.

Type 2. Hazardous imported substances, must obtain a certificate of registration and notify the government agencies responsible for those hazardous substances, and the occupant must pay annual fees and comply with the rules and procedures prescribed by the government agencies. Additionally, chemicals holder must follow the rules for disposal and destruction of dangerous objects.

Type 3. Dangerous substances; must obtain the item registration for dangerous goods and requires permit for produce, import, export or possession. The holders must pay annual fees and follow the rules and procedures of government for all operations.

Type 4. Prohibits substances, not allowed to produce, import, export, or occupy

\section{Public Health Act 1992 c}

This Act belongs to the Ministry of Public Health; responses about the business detrimental to health and the powers and duties of a Local official.

\section{Safety, Health and Working Environment Act 2011 a}

The related establishment which is the key item in this Act on the working in the industrial sector is exemplified in the following chapters:

Chapter 1. Establishes the employer's obligation to provide safety-working conditions for employees, and the employer must be responsible for all operating cost.

Chapter 2. Provides the management and implementation of the safety-working environment. The standard rules of working must be established and must comply with such standards.

Chapter 4. Requires employers to carry out hazard assessments and impact of working environment, then provides the operation for the safety-working plan and submit their assessment results and plans to the Department of Labour Protection.

Chapter 8. Impose penalties on employers who fail to comply with the law, punishment by imprisonment of up to 1 year without or with fine not more than four hundred thousand Baht.

As mentioned in the section 34 of this Act, if any severe incident is found or employees run into danger from their works, employers would conduct as follows:

1. If an employee runs into danger or illness in accordance with the Compensation Law after the employer reported to the Social security office, the employer would also submit a copy of the report to the safety inspector within 7 days.

2. If death and damaging found or working process have to stop producing their products. They shall report a Safety Inspector immediately (by telephone, papers, or others), the report must mention details about the cause of those issues; it should be submitted within 7 days using the provided form. After the Safety inspector was informed, the inspection and hazard precautionary actions have to be carried out without delay.

\section{Workmen's Compensation Act 1994 b}

In this Act, the main matter is in the Article 48. If the employee encounters injuries, illness, or disappearance, the employer must report the suffering of their employees to the local office or nearest office where factory is located within 15 days counting from the day after employer has been known of the loss suffering from injury, illness or disappearance of their employees.

Nowadays, there are several matters generally considered for security check according to the above acts, for example, the installation of machines, identification of proper working process, the impact of the factory to human and surrounding environment, investigation of the emergency plans and duty of the responsible divisions, including the verification of such plans. However, the accomplishment of the statutes is depending on the strictness of the government and the relevant ministries. If the examination by the government covers all the factories in the country, the industrial accidents will be significantly reduced. Moreover, knowledge on the operation provided by the entrepreneurs to their employees will help to reduce accidents as well.

\section{Conclusions}

The quicker the industrial growth, the higher fallibility were observed, particularly shown in the small industrial sectors. There are many possible reasons behind the misstep. The major accidents in the factory are caused by 
instruments, gadgets, and machines. In small-scale industry, the entrepreneurs sometimes do not have sufficient resources to replace the long-standing or malfunctioned machines. This might cause a machinery error and leads to the unexpected accidents. Second is the limitation of education. Numerous workers do not have enough technique, skill, or knowledge to operate the machinery, so this might cause the lack of safety in the workplace. The last weakness is the deficiency of the safety system, or disregarding of the safest way, including an unobtrusive of an employee. This type of accidents regularly occurs and is called human error. The legal implementation and policing by the local authority with the supervision of the central government are important steps to improve industrial safety standards. With such systematic actions, accident rates in Thai manufacturing industry will definitely decrease.

\section{Acknowledgments}

The author gratefully acknowledges the financial support by the Advanced Graduate Program in Global Strategy for Green Asia to conduct this study. The author would like to record her appreciation to Assist. Prof. Tomoaki Watanabe for his suggestion and comments.

\section{References}

1) United Nations Development Programme (UNDP), Human Development Report 2016, Human Development for Everyone., (2016) [Online], available http://hdr.undp.org/sites/default/files/2016_human_de velopment_report.pdf

2) P. Bożyk, "Newly Industrialized Countries". Globalization and the Transformation of Foreign Economic Policy. Ashgate Publishing, Ltd., p. 164 (2006).

3) Department of Industrial Works (Thailand), Industrial Database of ASEAN (IDAS) (in Thai), [Online], available at http://php.diw.go.th, accessed from November 2016 to January 2017.

4) Thai government gazette no. 90 (in Thai), 157, 3490, (1973).

5) Industrial Estate Authority of Thailand (in Thai). [Online], available at http://www.ieat.go.th, accessed from November 2016 to January 2017.

6) Safety and Health at Work Promotion Association (Thailand) (in Thai). [Online], available at http://www.shawpat.or.th

7) Office of the National Economic and Social Development Board Office of the Prime Minister Bangkok, Thailand, The Twelfth National Economic and Social Development Plan (2017-2021). [Online], available

http://www.nesdb.go.th/nesdb_en/ewt_w3c/ewt_dl_li nk.php?nid=4345

8) Department of Industrial work, Thailand (in Thai), (2017). [Online] available at http://www.diw.go.th, accessed from November 2016 to January 2017.

9) World Integrated Trade Solution (WITS). [Online], available at http://wits.worldbank.org

10) Safety Technology Bureau (in Thai). [Online], available at http://php.diw.go.th

11)H. Wei, L. Dang, M. Hoyle, Overview of Health and Safety in China, Symposium Series, 154 (2008).

12)A. Herbert, National Profile Report on Occupational Safety and Healthin China, (2012).

13)K. Reddy G, K. Yarrakula, International Journal of ChemTech Research, 9(4), 177-191 (2016).

14)R. Emmars, Resource Management and Contested Territories in East Asia, 10-14 (2013).

15)Y. Ye, S Zhang, J. Rao, H. Wang, Y. Li, S. Wang, and X. Dong, Analysis of National Major Work Safety Accidents in China, 2003-2012, Iran J Public Health. 45(1), 6-13 (2016).

16)G. Nakamura, T. Shiraishi, and T.Suzuki, Latest factory fatalities part of the big problem in Japan's chemical industry, (2014).

17)T. A. Kletz, Some Loss Prevention Case Histories, Process Safety Progress, 14(4), (1995).

18)D. H. Lim, J. H. Yoo, and J. W. Ko, A loss control management system for the petrochemical industry, Korean J. Chem. Eng., 26(6), ) 1423-1428 (2009).

19)K. Phusavat, P. Anussornnitisarn, S. Meeampol, S. Sooksmarn, B. Rassameethes, and T. Siripachana, A Networked Government: Learning from Thai Health Promotion Foundation on Accident Prevention (2013).

20)Ministry of Health, Labour and Welfare (Japan), 11th Industrial Accident Prevention Plan 2008 - 2012. [Online], available at https://www.jisha.or.jp

21)International Labour Office Geneva, Prevention of Major Industrial Accidents, (1991). [Online], available http://www.ilo.org/wcmsp5/groups/public/---ed_prote ct/---protrav/---safework/documents/normativeinstru ment/wcms_107829

22)Japan International Center for Occupational Safety and Health, Industrial Accident Prevention Plan (10th Industrial Accident Prevention Plan, from 2003 to 2007), (2003). [Online], available at 
https://www.jniosh.go.jp

23)B. Gransow, G. Zheng, A. Leong, and L. Ling, Chinese Migrant Workers and Occupational Injuries A Case Study of the Manufacturing Industry in the Pearl River Delta, (2014). [Online], available at http://hdl.handle.net/10419/148764

24)G. Hea, L. Zhang, Y. Lua, and A. P. J. Mol, Managing major chemical accidents in China: Towards effective risk information, Journal of Hazardous Materials, 187, 171-181 (2011).

25)Department of Industrial work Thailand, Chemical storage and measurement (in Thai), (2007). [Online], available at http://eis.diw.go.th/haz/hazard/pdf/pagad-kep-2550

26)A review of high-cost chemical/petrochemical accidents since Flixborough 1974, IchemE Loss Prevention Bulletin, 140 (1998).

27)G. Drogaris, Community Documentation Centre on Industrial Risk: Review of accidents involving unexpected/run-away reactions, (1992).

28)Public Health Act 1992 (in Thai). [Online], available at

http://hs.crru.ac.th/newhs2015/file/filewรบ.สาธารณสุข\%2 02535

29)P. Thepaksorn, and S. Pongpanich, Occupational Injuries and Illnesses and Associated Costs in Thailand, Safety and Health at Work, 5, 66-72 (2014).

30) Guideline of Hazardous Control of Thailand (in Thai). [Online], available at http://php.diw.go.th/haz/

31)K. Umaporn, Improvement of Policy on Occupational Safety and Health - From Policy Development to Implementation Measures, Bureau of Occupational Safety and Health, Department of Labour Protection and Welfare, (2016). 